\title{
DIVERSITY AND INTRAGROUP CONFLICT AT WORK: AN EMPIRICAL STUDY IN PORTUGAL
}

\section{DIVERSIDADE E CONFLITO INTRAGRUPAL NO TRABALHO: UM ESTUDO EMPÍRICO EM PORTUGAL}

\section{CARINE BASTOS DA FRANÇA}

Mestranda em Psicologia do Trabalho, das Organizações e dos Recursos Humanos pela Faculdade de Psicologia e Ciências da Educação da Universidade de Coimbra. Rua do Colégio Novo, Apartado 6153 - Coimbra - Portugal - CEP 3001-802 E-mail: carybastos@gmail.com

\section{PAULO RENATO LOURENÇO}

Doutor em Psicologia do Trabalho e das Organizações pela Faculdade de Psicologia e Ciências da Educação da Universidade de Coimbra. Professor auxiliar da Faculdade de Psicologia e Ciências da Educação da Universidade de Coimbra. Rua do Colégio Novo, Apartado 6153 - Coimbra - Portugal - CEP 3001-802 


\section{ABSTRACT}

Facing a constantly changing environment, nowadays' organizations are looking for innovative ways of organizing and managing work, in which workgroups represent a source of competitive advantage. In this context, group diversity has received increasingly attention by researchers. Jackson, May and Whitney (I995) define diversity in terms of characteristics classified as observable or underlying, as either task-related or relational-oriented. Although there are no conclusive results on this subject, researches relating diversity and the main types of conflict (affective and task-related) suggest that relational-oriented diversity (e.g., age, gender) influences the emergence of affective conflict, while task-oriented diversity (e.g., education, organizational tenure) contributes to task conflict (PELLED, I996; JEHN; NORTHCRAFT; NEALE, I999; PELLED; EISENHARDT; XIN, I999). Following Jackson, May and Whitney (I995), we analyzed the effects of observable attributes of diversity (educational level, gender and age), on the emergence of intragroup conflict in 23I Portuguese workgroups, whose members perceived themselves as a group, and interacted with interdependence to achieve common goals. The Intragroup Conflict Assessment Scale (DIMAS; LOURENÇO; MIGUEZ, 2007) and a sociodemographic questionnaire were used. In contrast with the literature, but congruent with recent Portuguese researches (PASSOS, 2005; SILVESTRE, 2008), our results revealed no association between the studied diversity variables and intragroup conflict, indicating new directions in this field, and highlighting the importance of considering different contexts and variables in diversity's studies.

\section{KEYWORDS}

Workgroups; Diversity; Intragroup conflict; Task-conflict; Affective conflit. 


\section{RESUMO}

Num ambiente de constantes mudanças, as organizações buscam novas formas de organizar e gerir o trabalho, nas quais os grupos de trabalho representam uma fonte de vantagem competitiva. Nesse contexto, a diversidade dos grupos tem recebido crescente atenção por parte dos pesquisadores. Jackson, May e Whitney (I995) definem diversidade em termos de características classificadas como observáveis ou subjacentes, bem como orientadas para a tarefa ou relação. Embora não haja resultados conclusivos nesse assunto, pesquisas relacionando diversidade e tipos de conflito (afetivo e orientado para a tarefa) sugerem que a diversidade orientada para a relação (por exemplo, idade, gênero) influencia a emergência de conflitos afetivos, enquanto a diversidade orientada para a tarefa (por exemplo, escolaridade, antiguidade na empresa) contribui para conflitos de tarefa (PELLED, I996; JEHN; NORTHCRAFT; NEALE, I999; PELLED; EISENHARDT; XIN, I999). Seguindo Jackson, May e Whitney (I995), analisamos os efeitos de atributos observáveis da diversidade (escolaridade, gênero e idade) na emergência do conflito intragrupal em 23I grupos de trabalho portugueses, cujos membros se percebiam como um grupo e interagiam com interdependência para o alcance de metas comuns. A escala de avaliação do conflito intragrupal (DIMAS; MIGUEZ; LOURENÇO, 2007) e um questionário sociodemográfico foram utilizados. Em contraste com a literatura, mas congruente com pesquisas recentes em Portugal (PASSOS, 2005; SILVESTRE, 2008), os resultados demonstraram não haver associação entre as variáveis estudadas de diversidade e o conflito intragrupal, apontando novas direções para a área e salientando a importância da consideração de diferentes contextos e variáveis no estudo da diversidade.

\section{PALAVRAS=CHAVE}

Grupos de trabalho; Diversidade; Conflito intragrupal; Conflito de tarefa; Conflito afetivo.

\section{INTRODUCTION}

The globalization of business economy and the interdepartmental and interorganizational strategic alliances set a complex organizational environment. Therefore, nowadays, almost all organizations are based on teams/workgroups, 
whose processes have been considered as a key element for organizational effectiveness. As an inescapable characteristic of contemporary organizations, workgroup diversity has recently received more attention, as a result of the internationalization of people from different cultures and minorities' insertion in the workforce. Indeed, in the last three decades, legislation in different countries has also been stimulating a growing number of organizations to promote equality and diversity at work (DICKENS, 2005; FERDMAN, I992; JACKSON; MAY; WHITNEY, I995; O'LEARY; WEATHINGTON, 2006; THOMAS, I999; KNIPPENBERG; SCHIPPERS, 2007).

Although literature suggests that group diversity may have both positive and negative effects on the group processes, the question is no more if diversity is good or bad, but which processes underlie its consequences and how to manage its challenges to take advantage of the potential benefits and better cope with possible difficulties. Indeed, the effects of this change in the workforce around the world are not yet understood and even the concept of diversity is still under different paradigms and meanings in both academic and organizational contexts (HERRIOT; PEMBERTON, I995; MILLIKEN; MARTINS, I996; PASSOS, 2005; REIS; CASTILLO; DUBÓN, 2007; SEMACHE, 2006; TRIANDIS; KUROWSKI; GELFAND, I994; WILLIAMS; O’REILLY, I998).

Nowadays, to appropriately manage diversity represents an alternative in order to create a competitive advantage for organizations (COX; BLAKE, I99I), since it could reduce costs with absenteeism and turnover, related to low job satisfaction and cultural conflicts, and offer more possibilities to reach diverse customers, as well as a broader base of ideas and experience, which could enhance creativity, innovation, organizational flexibility, and also improve problem solving and decision making.

Considering the influence of diversity on group processes, in the present research, we aim to study the relation between some attributes of diversity, namely educational background, gender, and age, and the two main types of intragroup conflict (affective and task-related), given that there is no consensus in literature. Since diversity has become a common characteristic of organizational life, and conflict is an inevitable phenomenon of the group's interaction, a better understanding of the relation between these variables can support the managing of groups and diversity in a more constructive way, in order to reach their whole potential.

We start this paper with a brief framework concerning the workgroup concept. Afterward, we analyze the concept of diversity itself, as well as some typologies and models proposed in literature to provide the understanding of this variable's effects on group processes. In the same way, we discuss the concept of conflict, as there is no unique definition for this phenomenon, even though it 
has been studied for a while. We also present some previous researches concerning the influence of diversity on the emergence of intragroup conflict at work. To accomplish our goals, we present an empirical study that we have conducted with Portuguese workgroups.

\section{LITERATURE REVIEW}

\subsection{GROUPS AND WORKGROUPS}

According to Arrow, McGrath and Berdahl (2000), groups are complex, adaptable and dynamic systems whose interactions and resources exchanged between members and context are regulated by permeable boundaries, being influenced by experience and environmental factors. Guzzo and Dickson (1996), in turn, consider a workgroup as individuals who consider each other and are considered as a social entity, interdependent in relation to the tasks to perform, and embedded in one or more larger social systems (e.g. community, organization).

In organizational context, both in field and academic community, groups have been frequently differentiated from teams, being this latter considered in a more positive way in the organizational context (ALBUQUERQUE; PUENTESPALACIOS, 2004; LEMOINE, 2003). Miguez and Lourenço (200I) discuss if there is effectively a distinction between those terms, considering that the use of "team" instead of "group" was due to a negative representation of the group in organizations, in contrast to a favorable representation of the team for management and effectiveness in organizations. However, considering the history, evolution and theories about groups, as well as the definition of teams in organizations, we follow a perspective that assumes both concepts as similar and referring to the same characteristics (GUZZO; DICKSON, I996; MIGUEZ; LOURENÇO, 200I).

From this approach, based on the socio-technical perspective, Lourenço (2002) defines group as a socio-technical system constituted by a set of individuals, which are interdependent and interact regularly, to achieve a common goal. The group is founded on two subsystems which are responsible for its development process: the affective, with the establishment of interdependent relationships among members, and the task subsystem, involving at least one perceived common goal to be achieved. The group is also remarked by temporal and psychological boundaries, which provide the perception of who is a member or not. We follow this perspective, considering groups as social systems, whose members have at least one common goal, are inter-related to achieve it, and perceive each other, as well as being perceived by the non-members, as a group. 


\subsection{WORKGROUP DIVERSITY}

Although there is a great amount of research in the field of workgroup diversity, it is also visible that there is an absence of consensus among researchers about this concept. Triandis, Kurowski and Gelfand (1994, p. 772) define diversity as "any attribute that humans are likely to tell themselves, 'That person is different from me'”. Fay and Yves (2007) adopt a similar definition, as well as Williams and O'Reilly (I998, p. 8I), who consider that "the effects of diversity can result from any attribute people use to tell themselves that another person is different". Those concepts are based on a social psychological perspective, according to which people have a natural tendency to use social categories, usually the most salient attributes, to simplify their experiences in the world. These latter authors propose a model that integrates the three most important theories on diversity's study: social categorization (TAJFEL, I978), similarity/attraction (BYRNE, I97I), and information/decision making.

Guzzo and Dickson (I996) define diversity as heterogeneity in terms of personalities, gender, attitudes, and background or experience in a group, while Knippenberg and Shippers $(2007$, p. $5 \mathrm{I} 6)$, following a wider sense, refer to "a characteristic of social grouping that reflects the degree to which objective or subjective differences exist between group members". Jehn, Northcraft and Neale (I999) proposed a typology conceiving three types of diversity, such as informational (e.g. knowledge, perspectives, educational background, experience, expertise), social category (e.g. race, gender, age) and value diversity (e.g. group goals, target or mission). Those dimensions are also adopted on researches conducted by Hobman, Bordia and Gallois $(2003,2004)$, which conceive diversity in terms of individual perceptions of dissimilarity to the workgroup.

In a systemic point of view, Jackson, May and Whitney (I995) proposed a general causal model, from the perspective that diversity, at the group level, is the presence of differences among members of a social unit, in terms of characteristics classified as observable or underlying, as either task-related or relational-oriented (Table I). According to the authors, readily detectable attributes are mostly immutable, easily and consensually determined with just a brief exposure to a specific person (e.g., gender, age, organizational/team tenure, educational level), while underlying attributes involve more possibilities of analysis and can be mutable (e.g., skills, knowledge, social status, values). Although Jackson, May and Whitney (I995) model, is not totally consensual among researchers - for example, educational background is classified by other authors (e.g., PELLED, I996) as a less visible demographic attribute -, the referred model, which supports our research, is considered a reference model in diversity studies. 


\section{TABLE I}

TYPOLOGY OF DIVE

\begin{tabular}{lll}
\hline ATTRIBUTES OF DIVERSITY & TASK-RELATED & RELATIONS-ORIENTED \\
\hline & & Gender \\
& Organizational/team tenure & Culture (race, ethnicity, \\
& Department or unit membership & nationality) \\
READILY DETECTABLEI & Membership in task-relevant & Age \\
OBSERVABLE ATTRIBUTES & external networks & Membership in formal \\
& Formal credentials & organizations (religious or \\
& Educational level & political) \\
& & Physical features \\
& & Social status \\
& Knowledge & Attitudes \\
& Skills & Values \\
& Abilities (cognitive and physical) & Personality characteristics \\
& Experience & Behavioral style \\
& & Extra-team social ties \\
\hline UNDERLYING ATTRIBUTES &
\end{tabular}

Source: Adapted from Jackson, May and Whitney (I995).

Considering these attributes, in general, most researches in organizational and group diversity tend to analyze the effects of observable and relationaloriented variables such as age, gender, and race/ethnicity (JACKSON; JOSHI; ERHARDT, 2003; MILLIKEN; MARTINS, I996; WILLIAMS; O'REILLY, I998). This tendency was confirmed by Reis, Castillo and Dobón (2007) in a recent review about the last fifty years of diversity studies, although they have also observed a focus on other readily detectable and task-related dimensions (e.g., group and organizational tenure, educational level, functional background). One explanation could be that observable attributes can be more easily measured and identified by researchers and organizational members.

\subsection{CONFLICT AND INTRAGROUP CONFLICT}

Conflict, allied to social integration and communication, has been one of the most frequently studied group processes (WILLIAMS; O'REILLY, I998). As with diversity, defining conflict is not a simple task, since there are different positions around its role on group and organizational life. Although conflict has usually been described as destructive and dangerous to a group's interaction, a more comprehensive view begins to emerge, conceiving it as a phenomenon that can 
have constructive or detrimental effects, depending on its management (DIMAS, 2007; JEHN, I994; MANNIX, 2003; RAHIM, 200I; THOMAS, I976, I992).

According to Thomas (I976, p. 89I), conflict is a process which includes perceptions, emotions, behaviors and outcomes of two parties and "begins when one party perceives that the other has frustrated, or is about to frustrate, some concern of his". Robbins (I978), in a similar but more general view, defines conflict as a perceived situation of opposition or antagonistic interaction between two or more parties. Searching for a more inclusive perspective, Rahim (2002, p. 207) conceptualizes conflict as "an interactive process manifested in incompatibility, disagreement, or dissonance within or between social entities (i.e., individual, group, organization, etc.)". As said by this author, conflict may occur not only in relation to an activity or function, but also in relation to preferences, values, attitudes and goals, when there is a perception that the limit of intensity was exceeded. Dimas, Lourenço and Miguez (2005), in turn, assume that, more than discordance, conflicts imply high levels of emotional involvement, perception of tension and opposition between parties. We follow this approach, which remarks that incompatibilities of goals or interests are not necessary, since a common goal can also lead to a conflict.

Concerning the different type of conflicts that can appear in a group and despite the diverse labels found in literature, most researchers distinguish between two dimensions, such as substantive/cognitive/task-related and relationship/ emotional/affective conflict (JEHN, I994, I995; DIMAS, 2007; DIMAS; LOURENÇO; MIGUEZ, 2005; PINKLEY, I990; RAHIM, 200I, 2002). Following Dimas, Lourenço and Miguez (2005), we consider the process conflict identified by Jehn (I997, p. 540) as actually related to the task, since it involves "how task accomplishment should proceed in the work unit, who's responsible for what and how things should be delegated".

In general, task-related conflict is characterized as oriented to activity, emerging from differences in judgment or perspective between two or more organizational members. It involves frustration, distrust, annoyance and tension based on perception of disagreements about the activity or content issues, viewpoints, ideas, opinions, goals and decisions, as well as procedures and choices for task accomplishment. Affective conflict is emotional related and refers to disputes in interpersonal relationships when group members become aware that their feelings and emotions to those issues are dissonant, also leading to frustration, distrust, annoyance and tension. Even if a group's members are able to distinguish between the two types of conflict, it doesn't mean that one cannot turn into the other if not adequately managed, since they are highly correlated to each other and can be aroused by similar conditions. The key factor to a better functioning in the group, thus, is developing the ability of managing both task and affective 
conflicts (AMASON; SAPIENZA, I997; ERUZUN, 2004; JEHN, I994, I995; PELLED, I996; RAHIM, 2002; SIMONS; PETERSON, 2000).

\subsection{DIVERSITY'S EFFECTS ON INTRAGROUP CONFLICTS}

When studying organizational workgroups, it is important to consider that each demographic attribute can have a different effect on their processes. Indeed, Williams and O'Reilly (I998) found that diversity can affect members (e.g., satisfaction, commitment) and group processes (e.g., communication, conflict), identifying several studies about the relation between educational background, age and gender diversity, and conflict.

Searching for an approach to analyze diversity's effects on conflict, Pelled (I996) proposed a model distinguishing demographic variables in terms of visibility and job-relatedness. She hypothesized that the more visible a demographic variable is, the more it is related to affective conflict and, the more job-related it is, the more associated with task conflict it is. The referred author also hypothesized that those influences would be reduced in time as the group's longevity increases. The model was tested by Pelled, Eisenhardt and Xin (I999), which, based on social categorization theory, pointed that visible attributes make it more difficult for people to identify, and, then, easily stereotype. As expected, the results revealed a positive relation between functional diversity and task conflict, as well as between race diversity and affective conflict. However, unexpectedly, there were no significant relations neither between gender diversity and any kind of intragroup conflict, nor between tenure diversity and task conflict. Actually, tenure diversity was positively associated with affective conflict, in contrast to age diversity, which, unlike expectations, showed a negative association with this type of conflict. All positive relations between diversity variables and both types of conflict tended to weaken through time.

Jehn, Nothcraft and Neale (I999) related conflict with the three-types of workgroup diversity included in their model (informational, social category, and value diversity), task interdependence and task type, observing a positive association between informational diversity (education and function) and task conflict, which the authors pointed as possibly beneficial for group outcomes. In contrast, social category diversity (gender and age) was positively associated with affective conflict, which could be more detrimental to group performance. Similarly to Pelled, Eisenhardt and Xin (I999), they also found that the negative effects of social differences reduce through time, though high levels of value diversity can be damaging at any phase of a group's life.

Considering that most researches in this topic have been conducted in USA companies, making findings less generalizable to other social-cultural settings, 
Pelled, Xin and Weiss (200I) conducted a study with Mexican workers to analyze the influence of individual dissimilarity on intragroup conflict in this context, and to verify whether conflict has the same two-dimensional structure in Mexico that it has in the US (task and affective). Mexican respondents indeed distinguished between different kinds of conflict experiences, revealing that the two dimensions of conflict may pass over different cultures. However, results did not follow the same pattern: while in US there was no significant association between age dissimilarity and emotional conflict, in Mexico there was a positive relation involving these constructs. Similarly, while in US studies, gender and tenure dissimilarity tended to enhance emotional conflict, in this Mexican sample the first attribute had no significant effect and the second was negatively associated to emotional conflict. Although this study was conducted at an individual level of analysis, it is important to stress the relevance of cultural differences in the study of conflict and diversity, namely in face of the inconsistent results from one country to another. Moreover, more researches are needed to better understand these relations at a workgroup level.

In a recent meta-analysis, relating diversity attributes, conflict and performance, De Wit and Greer (2008) found that both informational diversity (e.g., tenure, educational background, functional background) and social category diversity (e.g., race, gender, age, and nationality) were positively related to task conflict. However, when analyzing specific characteristics, a negative relation with task conflict was found for educational background and age. Relationship conflict was positively associated with tenure, informational and social category diversity. In this study, process conflict was also considered, which was positively related to social category diversity, and negatively to informational diversity. According to the authors, those findings should be taken carefully, since correlations were not so high and, even when moderators were considered, the relationships between diversity, conflict, and team outcomes were found to be very varied and complex, probably being better understood in the presence of several moderating factors simultaneously.

In Brazil, only recently diversity has been given more attention, mostly in function of the challenging scenario of competitiveness, multinational companies' insertion, mergers and acquisitions. In fact, even if Brazil has a history of cultural and social heterogeneity, due to the colonization period and all the immigrants from different countries in the last century, and that Brazilians have a self-image of not accepting prejudice and racial discrimination, there is still a great lack of opportunities in the labor market between people from different genders and races. Government laws are still very recent, as well as organizational interest in reducing those differences. Most concerned companies are north-American subsidiaries, which tend to monitor the head office's poli- 
cies and practices to evaluate the applicability and adaptation for the Brazilian reality. In general, organizations that adopt a diversity program in Brazil focus on recruiting and selecting more women and black people, providing training and development about cultural diversity for managers, and disseminating a program's goals through internal communication (FLEURY, 2000; TORRES; PÉREZ-NEBRA, 2004).

Indeed, considering the actual global context, with an increasing amount of expatriates around the world, other important challenges for human resources management in Brazil involve developing and disseminating an international mindset, thereby effectively managing diversity (CHU; WOOD JR., 2008; TANURE, 2005). In fact, organizations in Brazil consider diversity management not only as a moral and social matter, but also as a strategy to improve effectiveness and competitiveness. The idea is attracting and retaining the talents, no matter where they come from, but this vision relies on a cultural change, more open to diversity in work environment (HANASHIRO; CARVALHO, 2005).

Hanashiro and Queiroz (2006) studied 46 teams from four car companies in Brazil, searching for an association between demographic variables (age, gender, profession tenure, organizational tenure, group tenure, job area, and educational background) and group performance variables (creativity, deadlines accomplishment, investment, and general evaluation). The data was collected from the groups' coordinators and diversity was calculated through Blau's coefficient of variation. Contrary to expectations, the authors found no support for most of their hypothesis in the Brazilian sample, confirming a lack of consensus in diversity's study also in this context. In fact, only age, educational background and professional tenure had a positive relation with the general performance evaluation. However, the authors suggest that their findings point to a possible mediation effect of other group processes, such as communication and intragroup conflict, on this relationship between heterogeneity and group performance, and these effects should be more investigated in different workgroup contexts.

Exploring the effective implementation of an organization's diversity program, Saraiva and Irigaray (2009) observed that, in some cases, policies stay only in speeches. Diversity policies in Brazil still face the problem of embedded prejudices both from majority and minorities groups, allied to a compliant behavior of managers. Moreover, discriminatory conducts are rarely ever punished. Hence, there is a need, both for researchers and practitioners, of better understanding diversity management and its influence on group and organizational processes, in this context, to effectively promote adaptation and more equal policies.

Although some theoretical and empirical researches (e.g., JACKSON; JOSHI; ERHARDT, 2003; JEHN; NORTHCRAFT; NEALE, I999; MANNIX; 
NEALE, 2005; PELLED; EISENHARDT; XIN, I999; REIS; CASTILLO; DOBÓN, 2007; WILLIAMS; O'REILLY, I998) about diversity's influence on groups processes have observed a tendency of a negative effect, recent studies in this field have found no significant results. For instance, in Portuguese workgroups no empirical evidences of a relationship between diversity and conflict were found, pointing to non conclusive results on this subject (PASSOS, 2005; SILVESTRE, 2008).

In sum, despite the variety of findings related to demographic diversity effects on intragroup conflict, many studies point to an influence of task-related characteristics on task conflict and less consistent empirical evidence of positive association between variables as age, gender, and race/ethnicity on affective conflict. As exposed in this paper, there is no consensus on literature neither about the concept of diversity nor its positive/negative effects on workgroup processes (DE DREU; WEINGART, 2003; DIMAS, 2007; JACKSON; JOSHI; ERHARDT, 2003; MANNIX, 2003; PASSOS, 2005; HORWITZ; HORWITZ, 2007; REIS; CASTILLO; DOBÓN, 2007).

Thus, searching for a clearer explanation about this relationship, and considering both diversity and conflict as inevitable phenomena in organizations, we intend to investigate what is the impact of observable attributes of diversity, such as gender, age and educational background, on intragroup conflicts (task-related and affective) in Portuguese workgroups. In view of the conceptual and empirical literature, the following hypotheses are proposed:

- $\mathrm{H}_{\mathrm{I}}$ : Task-related attributes of diversity will be positively associated with intragroup task conflict.

- $\mathrm{H}_{2}$ : Relational oriented attributes of diversity will be positively related with intragroup affective conflict.

- $\mathrm{H}_{2 \mathrm{a}}$ : Gender diversity will have stronger association with affective conflict than age diversity.

\section{METHODOLOGY}

This research is a correlational and field study, being conducted with real workgroups, with no manipulation of variables and a reduced researcher's impact (MUCHINSKY, I990; PELLETIER; BOIVIN; ALAIN, 2000). The study is focused on group level analysis, given that our subjects are workgroups, and has a cross-sectional nature, since the data was collected at a single point in time from a specified population (VISSER; KROSNICK; LAVRAKAS, 2000). The indepen- 
dent variables studied were observational attributes of diversity, such as educational level (task oriented), gender and age (relational oriented). Although we have collected data related to other demographic attributes that we intended to investigate (e.g., group tenure, job tenure), those variables were not included in the study because of the high level of missing values, which did not allow us to statistically analyze them.

Task and affective conflict were the dependent variables. To assess the data, a self-ministered questionnaire was used. Despite the inconvenient aspects (e.g., social desirability influence, difficulties to understand the items and no opportunity to clarify, biased or unrepresentative answers of the group), this technique permits to appraise opinions, attitudes, preferences and behaviors, in a fairly structured way. Besides, it is a direct and low cost technique that can be applied in a large population, in a relatively short period, preserving anonymity, and, in the analysis stage, allowing data comparison (ANGERS, I996; GHIGLIONE; MATALON, I998; JAVEAU, I990; MUCHINSKY, I990).

\subsection{VARIABLES AND INSTRUMENTS}

\subsubsection{Diversity}

In order to assess workgroup diversity, a sociodemographic questionnaire was applied to each group member. Considering that our data are from categorical demographic variables (gender, age, and educational background), group diversity was measured by an entropy-based index suggested by Teachman (I980):

$$
\begin{gathered}
\mathrm{i} \\
\text { Entropy Index }=-\sum \mathrm{P}_{\mathrm{i}}\left(\text { In } \mathrm{P}_{\mathrm{i}}\right) \\
\mathrm{I}=\mathrm{I}
\end{gathered}
$$

$\mathrm{I}=$ number of categories in a variable,

$\mathrm{P}_{\mathrm{i}}=$ proportion of workgroup members in the variable's category.

This index, also adopted by Pelled (I996) and Pelled, Eisenhardt and Xin (I999), takes into account the distribution of workgroup members in each possible category of a variable. The greater the distribution across a variable, the higher its diversity score is. Following Alexander et al. (I993) and also Teachman

I The demographic attribute "age" was initially collected as a non-categorical variable. However, before starting the analysis process, we opted to transform it into different age categories (< 25 years; 25-34 years; 35-44 years; 45-54 years; > 54 years), and that explains why we adopted the entropy-based index also for this variable. 
(I980), we used the standardized form of the entropy-based diversity index as a control for the effects of category number (LIEBERSON, I969), to compare the variation degree between measures of diversity that differ in number of categories. To standardize, we divided the entropy index by its theoretical maximum, the neperian logarithm of $\mathrm{N}$ ( $\mathrm{N}=$ number of a variable categories). In this sense, all the diversity variables investigated in both researches conducted ranged from $\circ$ to I. More concentration on a specific diversity attribute (i.e., homogeneity) reflects a value of standardized diversity index equal to zero. In contrast, we identify more diversity from the highest values of the standardized index next to I.

\subsubsection{Intragroup Conflict}

In order to assess the type of intragroup conflict, the Intragroup Conflict Assessment Scale (escala de avaliação do conflito intragrupal - Eaci), developed by Dimas, Lourenço and Miguez (2007) was used. The scale's construction was based on a wide theoretical analysis of conflict and on the instruments developed by Jehn (I994) - the Intragroup Conflict Scale - and by De Dreu and Vienen (200I) - the Socio-affective Conflict Scale. Comparing with the previous scale, Eaci has, however, the advantage of emphasizing the tension involved in the conflict process. The Eaci measures the frequency of intragroup conflict through a seven point Likert scale (ranging from I - never happens to 7 - always happens). From the nine items that constitute the instrument, four represent the affective dimension (items I, 3 , 4, 9-e.g., "Manifestations of personal divergences among group members") and five are related to task conflict (items 2, 5, 6, 7, 8 - e.g., "Divergences concerning the distribution of work and responsibilities"). The participants indicate in which frequency, in their workgroup, tension related to any of the presented situations emerges.

This scale was chosen because it has already been applied in Portuguese organizational workgroups and previously submitted to validation processes of content, construct and reliability by the authors. In fact, they submitted the first version of Eaci to an Exploratory Factor Analysis through a Principal Component Analysis with varimax rotation $(\mathrm{N}=382)$, extracting two factors (task conflict and affective conflict), which explained $63 \%$ of the total variance $(\alpha=.85$ to task conflict; $\alpha=.80$ to affective conflict). In a second study, they conducted a Confirmatory Factor Analysis ( $\mathrm{N}=32 \mathrm{I}$ ) to test the bi-dimensionality found in the instrument. Results showed, once more, the good psychometric properties of the scale and confirmed the two factors (CFI $=.97)$, fact which was in congruence with the theoretical framework. Regarding the internal consistency, the Cronbach-alpha was .85 to task conflict dimension and .83 to affective conflict dimension, indicating high levels of reliability, giving that the minimum 
value usually accepted pointed by Hair et al. (2005) is .70. Other Portuguese researchers have also adopted this scale and confirmed its good psychometric properties (e.g., BASTOS, 2008 ( $\alpha=.87$ to task conflict; $\alpha=.84$ to affective conflict); CADIMA, 2009 ( $\alpha=.86$ to task conflict; $\alpha=.83$ to affective conflict); SILVESTRE, 2008 ( $\alpha=.86$ to task conflict; $\alpha=.86$ to affective conflict)). In this sense, we have only measured internal consistency, through a Cronbachalpha and an item-dimension correlation analysis, as it can be seen in Tablin our study, the two dimensions, Task Conflict and Affective Conflict, also revealed reliable levels of internal consistency ( $\alpha=.86 ; \alpha=.84$, respectively) (HAIR et al., 2005; NUNALLY, 1978). Analyzing the values of alpha if item deleted, it was not pointed the exclusion of any item in this scale. Correlations between each item and its respective factor were also satisfactory, since all of them were above .60, value which Nunally (1978) suggests as satisfactory.

\section{TABLE 2}

EACI: MEANS, STANDARD DEVIATION, CORRECTED ITEM

TOTAL CORRELATION, AND CRONBACH'S ALPHA EVALUATION (PORTUGUESE SAMPLE)

\begin{tabular}{|c|c|c|c|c|c|c|}
\hline FACTORS & ITEMS & MEAN & SD & $\begin{array}{l}\text { CORRECTED ITEM } \\
\text { TOTAL CORRELATION }\end{array}$ & $\begin{array}{l}\alpha \text { IF ITEM } \\
\text { DELETED }\end{array}$ & $\begin{array}{c}\text { ALPHA } \\
\alpha\end{array}$ \\
\hline \multicolumn{7}{|c|}{ TASK CONFLICT } \\
\hline & 2 & 2.84 & 1.33 & .67 & .84 & \multirow{5}{*}{.86} \\
\hline & 5 & 3.44 & 1.19 & .63 & .85 & \\
\hline & 6 & 3.09 & 1.20 & .74 & .82 & \\
\hline & 7 & 3.10 & 1.22 & .68 & .84 & \\
\hline & 8 & 2.77 & 1.29 & .71 & .83 & \\
\hline \multicolumn{7}{|c|}{ AFFECTIVE CONFLICT } \\
\hline & 1 & 3.03 & 1.25 & .62 & .81 & \multirow{4}{*}{.84} \\
\hline & 3 & 3.95 & 1.34 & .73 & .76 & \\
\hline & 4 & 2.86 & 1.27 & .66 & .80 & \\
\hline & 9 & 2.74 & 1.23 & .66 & .80 & \\
\hline
\end{tabular}

$\mathrm{N}=$ I04I 
Considering that intragroup conflict is a group level concept and that the data was collected from individuals through self-ministered questionnaires, we adopted indices of interrater agreement to guarantee that the individual data significantly represents the group's perception of conflict as a whole. Following Dimas (2007), we adopted the Average Deviation Index $\left(\mathrm{AD}_{\mathrm{M}}\right)$ (BURKE; DUNLAP, 2002; BURKE; FINKELSTEIN; DUSING, I999), whose main advantage is the existence of an objective upper-limit value, from which it is not assumed the agreement among judges. The $\mathrm{AD}_{\mathrm{M}}$ index is represented by the absolute difference between each individual answer to an item and the group's mean or median in the same item. For scales with several items, the $\mathrm{AD}_{\mathrm{M}}$ index is represented by the mean of all items' indices. The lowest is the index value, the highest is the agreement among the group members. This value can be calculated through the formula $\mathrm{c} / 6$ ( $\mathrm{c}=$ number of possible answers per item) and, if $A D_{M}>c / 6$, there is no assurance that the aggregated results really represent the group processes analyzed. Considering the metric of the Intragroup Conflict Assessment Scale, which involves seven options of answers, the confidence level of the index was $\mathrm{AD}_{\mathrm{M}} \leq$ I.I7. Then, every group that had a value above I.I7 was excluded from our analysis, as it is demonstrated in the results section.

\subsection{DATA COLLECTION}

To identify potential organizations to participate in our study, we analyzed the list of the best organizations to work in Portugal, published in a magazine's special edition of 2005 , and also conducted a survey on the internet. Personal and professional contacts were also important sources of information concerning the organizations interested in collaborating in our research. Thus, 600 organizations were selected. The first contact was made through a presentation letter, in which we explained the scientific objectives of our research, the collaboration needed from the organizations and the return that would be provided at the end of the study. The second contact was made by e-mail to reinforce the importance of participation. To those organizations that showed some interest in supporting our study, a research project was sent, which described our goals in a more detailed way, the type of information requested and the procedures of data collection.

Afterward, we made contact by phone, e-mail and even personally with organizations, to clarify all the points and to plan data collection. From the organizations to which our research team sent the project, 49 accepted to collaborate in our research, representing approximately $8.2 \%$ of participation. Identification and selection of workgroups (i.e., recognizing and being recognized as a team; 
having at least one common goal; interacting regularly in an interdependent way toward goal achievement) were conducted previously to data collection, with the support of an organizational member (usually HR Manager).

Data collection itself was conducted between October 2007 and April 2008. Questionnaires were distributed to each organization in different envelops with the name of each workgroup. Since the research team would not be present in all organizations, information about the participant's confidentiality and the importance to fulfill each and every item was also provided, as an attempt to reduce potential difficulties that can emerge in this situation (e.g., doubts not clarified that could lead to less trustful data and more missing values). The organizational member in contact with the research team distributed the correspondent envelop for each workgroup and, after its fulfilling, received, checked and delivered the envelops back to the research team. The identification of groups and organizations was made through a code number. In organizations where the researchers could be present, the data was collected during the work period. The workgroups selected were lead to a separate room in which the research team reinforced the instructions to guarantee data reliability. Each meeting took about I5 minutes.

\subsubsection{Sample}

Our sample was constituted by several Portuguese organizational workgroups, with a real history of development, missions and goals to accomplish. The initial sample was composed by 23I groups, constituted from 2 to 28 members, with a mean of 8 persons per group ( $S D=6 . \mathrm{I} 7)$, totalizing I04I participants. Following some other Portuguese researchers (e.g., BASTOS, 2008; CADIMA, 2009), we decided to include workgroups with a minimum of two members, because of the great number of groups in this situation $(\mathrm{N}=73)$, representing 31.6\% of our sample, and whose exclusion would significantly reduce our sample. We also justify this option considering that, in organizational contexts, groups with two elements are frequently constituted and recognized as groups/ teams by the organizational members.

Most part of the teams had less than 6 members (57\%) and worked in private organizations of industrial and service sectors in different types of activities: production $(36.3 \%)$, teaching (I4.9\%), commerce (9.6\%), administrative service $(8.4 \%)$, logistics $(6.9 \%)$, projects $(4.9 \%)$, maintenance $(3.7 \%)$, quality $(2.9 \%)$, marketing (г.6\%), accounting (1.3\%), and others (4.4\%).

As can be seen in more detail in Table 3, although the difference was not very high, most part of the sample was male $(\mathrm{n}=549)$, corresponding to $52.7 \%$ of the participants, and was between 25 and 34 years old (34.5\%). Indeed, 74.I\% 
of the subjects were less than 44 years old. Even though there were $28.5 \%$ of graduated participants, $68.6 \%$ have studied only until the $12^{\text {th }}$ grade (equivalent to high school in USA).

\section{TABLE 3}

\section{DEMOGRAPHIC CHARACTERISTICS (PORTUGUESE SAMPLE)}

\begin{tabular}{lcc}
\hline DEMOGRAPHIC ATTRIBUTE & $N$ & $\%$ \\
\hline GENDER & & \\
\hline Female & 486 & 47.0 \\
\hline Male & 549 & 53.0 \\
\hline AGE & 100 & \\
\hline$<25$ years & 359 & 9.7 \\
\hline 25 to 34 years & 303 & 34.9 \\
\hline 35 to 44 years & 204 & 29.4 \\
\hline 45 to 54 years & 63 & 19.8 \\
\hline$>54$ years & & 6.1 \\
\hline EDUCATIONAL BACKGROUND & 230 & \\
\hline Incomplete Basic $\left(<9^{\text {th }}\right.$ Grade) & 210 & 22.6 \\
\hline Basic (9th Grade) & 261 & 20.6 \\
\hline Secondary (12 & & \\
\hline Graduate & 297 & 29.6 \\
\hline Post-grade) & 21 & 2.1 \\
\hline
\end{tabular}

$\mathrm{N}=$ I04I

Source: Elaborated by authors.

\section{RESULTS}

As previously mentioned, in order to aggregate the data concerning intragroup conflict at a group level, we initially analyzed the $\mathrm{AD}_{\mathrm{M}}$ index, which varied 
from o (groups I29, I3I, I55, I98) to I.47 (group 96), with a mean of .68 (SD = .298) (Table 4). Then, to ascend from individual to group level, we were forced to eliminate $\mathrm{I} 6$ groups, since their values were higher than the reference calculated for EACI $\left(\mathrm{AD}_{\mathrm{M}} \leq \mathrm{I} . \mathrm{I} 7\right)$. Our sample was consequently reduced to $2 \mathrm{I} 5$ groups, constituted from 2 to 20 members, with a mean of 4 per group $(S D=3.31)$, totalizing 945 participants. The majority of groups were composed by less than 6 subjects $(84.2 \%)$ and no missing values to the scale responses were verified.

\section{TABLE 4}

$\mathrm{AD}_{\mathrm{M}}$ INDEX DESCRIPTIVE STATISTICS FOR EACI

(PORTUGUESE SAMPLE)

\begin{tabular}{ccccc} 
& MINIMUM & MAXIMUM & MEAN & SD \\
\hline Eaci & .00 & 1.47 & .68 & .30 \\
\hline
\end{tabular}

Source: Elaborated by authors.

Searching for answers to our research questions, we first analyzed the correlations between our independent variables and the two dimensions of intragroup conflict. Observing Table 5, we verify that age diversity has very low and statistically non significant correlation both with affective conflict $[r=.035(N=2 \mathrm{I} 5 ; p=.605)]$ and task conflict $[r=.073(N=215 ; p=.290)]$.

The same trend was observed for gender diversity, which also had a low association with affective conflict $[r=.070(N=215 ; p=.304)]$ and with task conflict $[r=.059(N=215 ; p=.389)]$, and for educational background diversity, which presented a non significant correlation both with affective conflict $[r=$ $.006(N=215 ; p=.926)]$, and with task conflict $[r=.026(N=215 ; p=.70 \mathrm{I})]$, as well. Thus, we found no support for our hypotheses I and 2, given that there was no correlation between task-oriented attributes of diversity and task-related conflict and there was, also, no correlation between relational-oriented attributes of diversity and affective conflict. Considering that no associations were found between gender diversity and affective conflict, nor between age diversity and affective conflict, our hypothesis za was also not supported. However, according to other researches on this topic, we observe high and significant correlation between the two dimensions of intragroup conflict $(r=.83, p=.000)$, confirming that task-related and affective conflict are not independent nor separated from each other. 


\section{TABLE 5}

CONFLICT DIMENSIONS AND WORKGROUP DIVERSITY CORRELATIONS, MEANS AND STANDARD DEVIATIONS

\begin{tabular}{|c|c|c|c|c|c|}
\hline & $\begin{array}{l}\text { AFFECTIVE } \\
\text { CONFLICT }\end{array}$ & $\begin{array}{c}\text { TASK } \\
\text { CONFLICT }\end{array}$ & AGE & GENDER & $\begin{array}{l}\text { EDUCATION } \\
\text { BACKGROUND }\end{array}$ \\
\hline Affective Conflict & - & & & & \\
\hline Task Conflict & $.83^{* *}$ & - & & & \\
\hline Age & .04 & .07 & - & & \\
\hline Gender & .07 & .06 & $.16^{*}$ & - & \\
\hline Educational Background & .01 & .03 & $.33^{* *}$ & -.05 & - \\
\hline Mean & 2.81 & 2.92 & .43 & .38 & .32 \\
\hline SD & .05 & .05 & .02 & .03 & .02 \\
\hline $\mathrm{N}$ & 215 & 215 & 215 & 215 & 215 \\
\hline
\end{tabular}

$* \mathrm{p}<0.05, * * \mathrm{p}<0.01$

Source: Elaborated by authors.

Analyzing our findings, we observe that there is no correlation between our workgroup diversity attributes (age, gender, and educational background) and both dimensions of intragroup conflict (affective and task-related). After the previous analysis, in face of no significant relationships between the variables studied, we decided not to continue with the following study procedures, which would involve the regression analysis technique.

\section{DISCUSSION}

In spite of the increasing importance currently given to workgroups, it is still a big challenge to better understand their processes and effects in the organizational context. Considering that most studies have been conducted with northAmerican workgroups and companies, as well as the inconclusive findings in literature related to group composition, we can say that generalizations on this field of research are not easy to be made.

Our purpose in the present study was to analyze the relationship between diversity and intragroup conflict in Portuguese workgroups, searching for more 
information about this process in a less referred context. Following the typology suggested by Jackson, May and Whitney (I995), we particularly focused on gender and age diversity, which are both observable and relational-oriented attributes, as well as on educational background diversity, classified as an observable and task-oriented attribute.

We adopted the same concept of intragroup conflict followed by Dimas, Lourenço and Miguez (2007), who consider two interrelated dimensions: task and affective conflict. As in previous researches (AMASON; SAPIENZA, I997; BASTOS, 2008; CADIMA, 2009; DIMAS, 2007; ERUZUN, 2004; JEHN, I994, I995; MCGURK, 2002; PELLED, I996; PELLED; EISENHARDT; XIN, I999; SILVESTRE, 2008), we have also observed a high association between these dimensions, suggesting that, even if group members are able to distinguish between task and affective conflict, one may turn into the other if not adequately managed.

From the literature review and the previous findings about the relationship between diversity and intragroup conflict, we stated some hypotheses related to the aforementioned specific attributes and dimensions. According to the social categorization (TAJFEL, I978; TURNER, I982) and similarity/attraction (BYRNE, I97I) theories, diversity would lead to more conflict, considering that individuals have a natural tendency to categorize each other and define one's social identity using the most salient or immediately observable categories, as well as to be attracted for the others who are more similar to them. At the same time, the paradigm of information/decision making suggests a positive association between task-oriented diversity and task conflict (ANCONA; CALDWELL, I992; JEHN; NORTHCRAFT; NEALE, I999; PELLED; EISENHARDT; XIN, I999; PELLED; XIN; WEISS, 200I; TZINER; EDEN, I985). However, our statistical analyses have not provided support for these assumptions. In fact, none of the diversity attributes studied, relational or task-oriented, showed a significant correlation with the dimensions of intragroup conflict in this Portuguese sample. As a result, our hypotheses were not supported.

Even though our findings are not congruent with most previous works on this topic, we have observed that some recent researches in the same context have also found no relationship between the same diversity attributes and intragroup conflict (PASSOS, 2005; SILVESTRE, 2008). Indeed, our findings highlight the importance of considering and including cultures other than the north-American, in order to understand the dynamic of diversity in different contexts and situations.

In an environment with a crescent internationalization of the workforce, it is relevant to analyze the effects of various demographic and cultural characteristics in the same organization or workgroup. This is a big challenge both for scientists and practitioners all around the world, since only few studies have 
focused on this subject in regions such as Asia, Latin America or Africa. Specifically in Brazil, the research field about diversity's influence on workgroup processes is still in a first development phase, even if the country is both naturally heterogeneous and socially unequal. However, government and organizations, mainly the multinational companies, have given more attention to policies and programs related to handicap insertion, gender and race/ethnicity diversity. This last attribute can, actually, be significantly representative in this context, since a predominant heterogeneous population does not mean equal career opportunities, as a consequence of the discriminatory perspective, along the country's History (CHU; WOOD JR., 2008; FLEURY, 2000; HANASHIRO; CARVALHO, 2005; SARAIVA; IRIGARAY, 2009; TORRES; PÉREZ-NEBRA, 2004).

In this sense, our results point out to new possible directions in diversity's study field, highlighting the importance of understanding its effects not only on intragroup conflict, but also on different workgroups processes, contexts and situations, which may be more related to group effectiveness (e.g., performance, innovation, satisfaction). Indeed, conflict involves tension, frustration, antagonism and annoyance among the parties, aspects that do not seem to be necessarily associated with diversity, as pointed by our findings. Possibly, studying the relationship between diversity and divergence, instead of intragroup conflict, could provide more clear and conclusive results. Divergence involves disagreement but does not entail intense emotions neither affect the relationship between the two parties (THOMAS, I976; ROBBINS, I978).

Even if divergence and conflict are distinct processes, it is possible that previous studies that have found positive associations between diversity attributes and intragroup conflict have not made such differentiation in their measures. Perhaps, they are more likely to be related to divergence than to conflict itself, focusing on disagreements, and not necessarily on the emotional involvement of the parties, as it can be observed in Jehn studies (I994, I995), whose instrument is one of the most used in this field. In that instrument, it is not so clear if the measurement refers to conflict or divergence (e.g., "How often do people in your work unit disagree about opinions regarding the work being done?"), aspect that could lead to biased results and conclusions. As a matter of fact, in a recent work, Jehn et al. (2008), recognized this limitation in Jehn's previous instrument. Those authors developed an extended tool to measure intragroup conflict, contemplating both the types (task, relationship and process conflict) and dimensions proposed in Jehn's (I997) model (emotionality, norms, resolution potential or efficacy, and importance). Hence, they suggest that this new instrument, which would really involve conflict's essential characteristics, could provide a less limited view and a better understanding about intragroup conflict in future researches. 


\section{CONCLUSION}

Regardless of the amount of researches already conducted in the field of diversity and workgroups processes, the relationship between this variable and the emergence of intragroup conflict remains unclear. Different studies, mostly conducted in north-American contexts, point to positive, negative or even no association between these constructs, and such a variety of results leads to a difficulty in establishing definitive and generalizable conclusions.

Always bearing in mind that our study was conducted with Portuguese workgroups, we observed that our findings suggested a lack of support for the assumptions that consider diversity as an antecedent of conflict. In fact, we observed no relationship between the diversity attributes studied (age, gender, and educational background) and the dimensions of intragroup conflict here adopted (task-related and affective conflict).

The fact that our study was conducted in a context different from that of most studies is a very important issue to have in account. Indeed, if, for instance, we consider previous Portuguese works on this topic (PASSOS, 2005; SILVESTRE, 2008), we can conclude that our study has been congruent with them, since no significant correlations were also observed between most attributes of diversity studied and the dimensions of intragroup conflict.

Our research, however, also had some limitations. In fact, we have studied only observable attributes of diversity (age and gender as relational-oriented, and educational background as task-oriented), according to the model here adopted, because they can more easily be measured and identified by group members. Moreover, as referred by Hanashiro and Queiroz (2006), it seems that immediately visible diversity attributes may have limited effect to explain workgroup processes and performance, suggesting the need of more investigations also including underlying aspects of diversity. However, the variables that were not included (e.g., group tenure, job tenure) could have contributed to our research findings, but the high number of missing information about these attributes did not allow us to conduct the statistical analysis. This limitation is also related to the fact that the self-responded questionnaires were, mostly, filled in without the presence of the researchers, who could have controlled better the non-responded items. In order to provide more conclusive results, future researches, in Portugal or other contexts, should consider different observable attributes of diversity, as well as underlying attributes, both task and relational-oriented.

Furthermore, longitudinal studies should be conducted to verify the dynamic nature of diversity and its effects on group processes such as intragroup conflict. Another important aspect to be considered in future researches is the unclear influence of mediating or moderating effects of different factors (e.g., 
group openness to diversity, group development and longevity, task complexity, organizational and group tenure, management of diversity and intragroup conflict) on this relation, as well as its influence on job outcomes (e.g., group performance, job satisfaction, group involvement, organizational commitment, absenteeism, turnover).

Intragroup conflict is certainly a big challenge for scientists and practitioners in organizations, since it can lead to positive or negative effects, depending on the situation, characteristics, and practices of management. In spite of the ambiguous findings, one practical aspect is already clear: independently of its type, conflict should be adequately managed to bring up some benefits for groups and organizations. It is also important for both managers and researchers to have in mind that managing and better understanding diversity represents much more than just accomplishing anti-discrimination laws. As with intragroup conflict, diversity represents an unavoidable characteristic of contemporary workgroups, searching for ways to maximize their potential and minimize possible detrimental aspects both for members and organizations.

From our findings, we could suggest that perhaps people working in groups could already be looking beyond the differences and establishing more comprehensive relationships at work. If diversity has no relation with intragroup conflict, maybe these constructs are indeed starting to be considered as usual characteristics of the work environment. Probably other factors would be related to the antecedents of conflict, as well as to the consequents of diversity, or maybe diversity's studies should take a new path to better contribute to understanding workgroup processes. Besides, as previously mentioned, focusing on the distinction between group members' divergence, instead of conflict, could also provide more conclusive results, since this question has not been well defined in most empirical researches carried out until this moment, which were usually based on instruments that actually did not measure the main components of conflict. Thus, it could be that diversity has an influence on workgroup divergence, which could be mostly positive, in terms of providing different ideas and perspectives on the group. However, more studies are still necessary in order to bring in a more sustained conclusion for these issues and clarify what differences at work really mean for workgroups in this new, dynamic and complex work environment.

\section{REFERENCES}

ALBUQUERQUE, F. J. B. de; PUENTES-PALACIOS, K. E. Grupos e equipes de trabalho. In: ZANELLI, J. C.; BORGES-ANDRADE J. E.; BASTOS, A.V. B. (Ed.). Psicologia, organizações e trabatho no Brasil. Porto Alegre: Artmed, 2004. p. 357-379. 
ALEXANDER, J. et al. Organizational demography and turnover: an examination of multiform and nonlinear heterogeneity. Human Relations, Berkeley, CA, v. 48, n. I2, p. I455-I480, I993.

AMASON, A. C.; SAPIENZA, H. J. The effects of top management team size and interaction norms on cognitive and affective conflict. Journal of Management, Briarcliff, NY, v. 23, p. 496-516, I997.

ANCONA, D. G.; CALDWELL, D. F. Demography and design: predictors of new product team performance. Organization Science, Hanover, v. 3, n. 3, p. 32I-34I, I992.

ANGERS, M. Initiation pratique à la méthodologie des sciences humaines. Anjou, Quebéc: CEC, I996. ARROW, H.; MCGRATH, J. E.; BERDAHL, J. L. Groups as complex systems - overview of the theory. In: (Ed.). Small groups as complex systems - formation, coordination, development and adaptation. London: Sage Publications, 2000. p. 33-57.

BASTOS, C. D. F. de. Cultura e conflitos: relação entre a orientação cultural para a aprendizagem nos grupos e os conflitos intragrupais. 2008. Dissertação (Mestrado em Psicologia Organizacional e do Trabalho)-Faculdade de Psicologia e Ciências da Educação, Universidade de Coimbra, Coimbra, 2008.

BURKE, M. J.; DUNLAP, W. P. Estimating interrater agreement with the average deviation index: a user's guide. Organizational Research Methods, Briarcliff Manor, NY, v. 5, n. 2, p. I59-I72, 2002.

BURKE, M. J.; FINKELSTEIN, L. M.; DUSIG, M. S. On average deviation indices for estimating interrater agreement. Organizational Research Methods, Briarcliff Manor, NY, v. 2, n. I, p. 49-68, I999.

BYRNE, D. E. The attraction paradigm. New York: Academic Press, I97I.

CADIMA, L. M. de M. A interdependência e a emergência de conflito intragrupal: que (inter)relação? Dissertation (Master in Work and Organizational Psychology). Faculdade de Psicologia e Ciências da Educação, Universidade de Coimbra, 2009.

CHU, R. A.; WOOD JR., T. Cultura organizacional brasileira pós-globalização: global ou local? RAP - Revista de Administração Pública, Rio de Janeiro, v. 42, n. 5, p. 969-99I, set./out. 2008.

COX, T. H.; BLAKE, S. Managing cultural diversity: implications for organizational competitiveness. Academy of Management Executive, Briarcliff Manor, NY, v. 5, n. 3, p. 45-56, I99I.

DE DREU, C. K. W.; VIANEN, A. E. M. Van. Managing relationship conflict and the effectiveness of organizational teams. Journal of Organizational Behavior, Hoboken, NJ, v. 22, n. 3, p. 309-328, 2001. DE DREU, C. K. W.; WEINGART, L. R. Task versus relationship conflict, team performance, and team member satisfaction: a meta-analysis. Journal of Applied Psychology, Washingtom, DC, v. 88, p. 74I-749, 2003.

DE WIT, F. R. C.; GREER, L. L. The black-box deciphered: a meta-analysis of team diversity, conflict, and team performance. In: THE ACADEMY OF MANAGEMENT ANNUAL MEETING PROCEEDINGS, 2008, Anaheim. Proceedings..., 2008.

DICKENS, L. Walking the talk? Equality and diversity in employment. In: BACH, S. (Ed.). Managing human resources: personnel management in transition. Oxford: Blackwell, 2005. p. I78-208.

DIMAS, I. C. D. (Re)pensar o conflito intragrupal: níveis de desenvolvimento e eficácia. 2007. Dissertação (Mestrado em Psicologia Organizacional e do Trabalho)-Faculdade de Psicologia e Ciências da Educação, Universidade de Coimbra, Coimbra, 2007.

DIMAS, I. D.; LOURENÇO, P. R.; MIGUEZ, J. Conflitos e desenvolvimento nos grupos e equipas de trabalho - uma abordagem integrada. Psychologica, Coimbra, v. 38, p. I03-II9, 2005. 
DIMAS, I. D.; LOURENÇO, P. R.; MIGUEZ, J. (Re)pensar os conflitos intragrupais: desempenho e níveis de desenvolvimento. Psicologia, Lisboa, v. XXI, n. 2, p. I83-205, 2007.

DOLAN, S.; LAMOUREUX, G.; GOSSELIN, E. Psychologie du travail et des organisations. Montréal, Paris: Gaëtan Morin, I990.

ERUZUN, A. Affective and substantive conflicts and interpersonal conflict management styles in the Turkish organizational context. 2004. Dissertation (Master of Arts in Conflict Analysis and Resolution)-Sabanci University, Istanbul, Turkey, 2004.

FAY, D.; YVES, G. R. F. Team diversity. In: CLEGG, S.; BAILEY, J. R. (Ed.). International encyclopedia of organization studies. Thousand Oaks, CA: Sage, 2007. p. I510-I513.

FERDMAN, B. M. The dynamics of ethnic in organizations: toward integrative models. In: KELLEY, K. (Ed.). Issues, theory and research in industrial/organizational psychology. Amsterdam: Elsevier Science, I992. p. 339-384.

FLEURY, M. T. L. Gerenciando a diversidade cultural: experiência de empresas brasileiras. RAE Revista de Administração de Empresas, São Paulo, v. 40, n. 3, jul./set. 2000.

GHIGLIONE, R.; MATALON, B. Les enquêtes sociologiques. Paris: Armand Colin, I998.

GUZZO, R. A.; DICKSON, M. V. Teams in organizations: recent research on performance and effectiveness. Annual Review of Psychology, Palo Alto, CA, v. 47, p. 307-338, I996.

HAIR, J. F. et al. Análise multivariada de dados. Porto Alegre: Bookman, 2005.

HANASHIRO, D. M. M.; CARVALHO, S. G. de. Diversidade cultural: panorama atual e reflexões para a realidade brasileira. REAd - Revista de Administração, Porto Alegre, v. II, n. 5, set./ out. 2005 .

HANASHIRO, D. M. M.; QUEIROZ, R. C. O efeito da diversidade nos times multifuncionais: um estudo na indústria automobilística. In: ENCONTRO NACIONAL DOS PROGRAMAS DE PÓSGRADUAÇÃO EM ADMINISTRAÇÃO, 30., 2006, Rio de Janeiro. Anais... Rio de Janeiro: Anpad, 2006.

HERRIOT, P.; PEMBERTON, C. Diversity as strength. In: (Ed.). Competitive advantage through diversity: organizational learning from difference. London: Sage, I995. p. 8-2I.

HOBMAN, E. V.; BORDIA, P.; GALLOIS, C. Consequences of feeling dissimilar from others in a work team. Journal of Business and Psychology, Dordrecht, v. I7, n. 3, p. 30I-325, 2003.

Perceived dissimilarity and work group involvement: the moderating effects of group openness to diversity. Group and Organization Management, Briarcliff Manor, NY, v. 29, n. 5, p. $560-587,2004$.

HORWITZ, S. K.; HORWITZ, I. B. The effects of team diversity on team outcomes: a meta-analytic review of team demography. Journal of Management, Briarcliff Manor, NY, v. 33, p. 987-10I6, 2007. JACKSON, S. E.; JOSHI, A.; ERHARDT, N. L. Recent research on team and organizational diversity: Swot analysis and implications. Journal of Management, Briarcliff Manor, NY, v. 29, n. 6, p. 8 oI$830,2003$.

JACKSON, S. E.; MAY, K. E.; WHITNEY, K. Understanding the dynamics of diversity in decisionmaking teams. In: GUZZO, R. A.; SALAS, E. (Ed.). Team effectiveness and decision making in organizations. San Francisco: Jossey-Bass, I995. p. 204-261.

JAVEAU, C. L'enquete par questionaire, manuel a l'usage du praticien. Bruxelles: Editions de l'Université de Bruxelles, I990. 
JEHN, K. A. Enhancing effectiveness: an investigation of advantages and disadvantages of valuebased intragroup conflict. International Journal of Conflict Management, Bingley, UK, v. II, n. I, p. 56-73, I994.

A multimethod examination of the benefits and detriments of intragroup conflict. Administrative Science Quarterly, Ithaca, NY, v. 40, n. 2, p. 256-282, I995.

A qualitative analyses of conflict types and dimensions in organizational groups. Administrative Science Quarterly, Ithaca, NY, v. 42, n. 3, p. 530-557, I997.

JEHN, K. A.; NORTHCRAFT, G. B.; NEALE, M. A. Why differences make a difference: a field study of diversity, conflict, and performance in workgroups. Administrative Science Quarterly, Ithaca, NY, v. 44, n. 4, p. 74I-764, I99.

JEHN, K. A. et al. The effects of conflict types, dimensions, and emergent states on group outcomes. Group Decision and Negotiation, Dordrecht, v. I7, n. 6, p. 465-495, 2008.

LEMOINE, C. Psychologie dans le travail et les organisations: relations humaines et enterprise. Paris: Dunod, 2003.

KNIPPENBERG, D. Van; SCHIPPERS, M. C. Work group diversity. Annual Review of Psychology, Palo Alto, CA, v. 58, p. 5I5-54I, 2007.

LIEBERSON, S. Measuring population diversity. American Sociological Review, v. 34, n. 6, p. $850-$ $862,1969$.

LOURENÇO, P. R. Concepções e dimensões da eficácia grupal: desempenho e níveis de desenvolvimento. 2002. Dissertação (Mestrado em Psicologia Organizacional e do Trabalho)-Faculdade de Psicologia e Ciências da Educação, Universidade de Coimbra, Coimbra, 2002.

MANNIX, E. Editor's comments: conflict and conflict resolution - a return to theorizing. Academic of Management Review, Briarcliff, NY, v. 28, n. 4, p. 534-546, 2003.

MANNIX, E.; NEALE, M. A. What differences make a difference? The promise and reality of diverse teams in organizations. Psychology Science, Washington, DC, v. 6, n. 2, p. 3I-56, 2005.

MCGURK, D. The effects of diversity on intragroup conflict and performance in the U.S. Army Reserve Officer Training Corps (ROTC). 2002. Dissertation in Psychology (Doctorate of Philosophy)-Texas Tech University, Lubbock, 2002.

MIGUEZ, J.; LOURENÇO, P. R. Qual a contribuição da metáfora "equipa” para a abordagem da eficácia organizacional? In: ENCONTRO LUSO-ESPANHOL DE PSICOLOGIA SOCIAL, 4. 200I, Porto. Paper... Porto, 9 nov. $200 \mathrm{I}$.

MILLIKEN, F. J.; MARTINS, L. L. Searching for common threads: Understanding the multiple effects of diversity in organizational groups. Academy of Management Review, v. 2I, p. 402-433, I996.

MUCHINSKY, P. M. Psichology applied to work: an introduction to industrial and organizational psychology. Belmont: Brooks, Cole Publishing, I990.

NUNALLY, J. Psychometric theory. New York: McGraw-Hill, I978.

O'LEARY, B. J.; WEATHINGTON, B. L. Beyond the business case for diversity in organizations. Employee Responsibilities and Rights Journal, New York, v. I8, n. 4, p. I-Io, 2006.

PASSOS, A. M. S. L. Contributos para a explicação do funcionamento das equipas de trabalho: o papel da diversidade e do conflito intragrupal. 2005. Dissertação (Mestrado em Psicologia Organizacional e Social)-Instituto Superior de Ciências do Trabalho e da Empresa, Lisboa, 2005. 
PELLED, L. H. Demographic diversity, conflict, and work group outcomes: an intervening process theory. Organization Science, Hanover, MD, v. 7, n. 6, p. 6I5-63I, I996.

PELLED, L. H.; EISENHARDT, K. M.; XIN, K. R. Exploring the black box: an analysis of work group diversity, conflict, and performance. Administrative Science Quarterly, Ithaca, NY, v. 44, p. I-28, I999. PELLED, L. H.; XIN, K. R.; WEISS, A. M. No es como mi: relational demography and conflict in a Mexican production facility. Journal of Occupational and Organisational Psychology, Leicester, NY, v. 74, p. 63-84, 2001 .

PELLETIER, L. G.; BOIVIN, M.; ALAIN, M. Les plans de recherche corrélationnels. In: VALLERAND, R. J.; HESS, U. (Ed.). Méthodes de recherche en psychologie. Montréal: Gäetan Morin Éditeur Itée, 2000. p. I93-222.

PINKLEY, R. L. Dimensions of conflict frame: disputant interpretations of conflict. Journal of Applied Psychology, Washington, DC, v. 75, p. II7-I26, I990.

RAHIM, M. A. Managing conflicts in organizations. Westport: Quorum Books, $200 \mathrm{I}$.

Toward a theory of managing organizational conflict. The International Journal of Conflict Management, Bingley, UK, v. I3, n. 3, p. 206-235, 2002.

REIS, C. R. de A. dos; CASTILLO, M. Á. S.; DOBÓN, S. R. Diversity and business performance: 50 years of research. Service Business, Heidelberg, Germany, v. I, p. 257-274, 2007.

ROBBINS, S. P. "Conflict management" and "conflict resolution" are not synonymous terms. California Management Review, Berkeley, CA, v. 2I, n. 2, p. 67-75, I978.

SARAIVA, L. A. S.; IRIGARAY, H. A. dos R. Políticas de diversidade nas organizações: uma questão de discurso? RAE - Revista de Administração de Empresas, São Paulo, v. 49, n. 3, p. 337-348, jul./ set. 2009.

SEMACHE, S. La diversité au coeur des équipes: quels enjeux? Quelles méthodes de management? Quelle place pour le management intermédiaire? Revue, Management et Avenir, Soliers, v. Io, p. I992II, 2006.

SILVESTRE, R. Os efeitos da variedade de composição demográfica no conflito intragrupal. 2008. Dissertação (Mestrado em Psicologia Organizacional e do Trabalho)-Faculdade de Psicologia e de Ciências da Educação, Universidade de Coimbra, Coimbra, 2008.

SIMONS, T. L.; PETERSON, R. S. Task conflict and relationship conflict in top management teams: the pivotal role of intragroup trust. Journal of Applied Psychology, Washington, DC, v. 85, p. IO2-III, 2000.

TAJFEL, H. Social categorization, social identity and social comparison. In: (Ed.). Differentiation between social groups: studies in the social psychology of intergroup relations. London: Academic Press, 1978. p. 6i-76.

TANURE, B. Human resource management in Brazil. In: ELVIRA, M. M.; DAVILA, A. Managing human resource in Latin America: an agenda for international leaders. Oxon: Routledge, 2005. p. III-I27.

TEACHMAN, J. D. Analysis of population diversity: measures of qualitative variation. Sociological Methods and Research, Thousands Oaks, CA, v. 8, n. 3, p. 34I-362, I980.

THOMAS, D. C. Cultural diversity and workgroup effectiveness: an experimental study. Journal of Cross-Cultural Psychology, Washington, DC, v. 30, n. 2, p. 242-263, I999.

THOMAS, K. W. Conflict and conflict Management. In: DUNNETTE, M. D. (Ed.). Handbook of industrial and organizational psychology. Chicago: Rand McNally, I976. p. 889-935. 
THOMAS, K. W. Conflict and negotiation processes in organizations. In: DUNNETTE, M. D.; HOUGH, L. M. (Ed.). Handbook of industrial and organizational psychology. Palo Alto, California: Consulting Psychologists Press, I992. v. 3, p. 65I-7I7.

TORRES, C. V.; PÉREZ-NEBRA, A. R. Diversidade no contexto organizacional. In: ZANELLI, J. C.; BORGES-ANDRADE, J. E.; BASTOS, A. V. B. (Ed.). Psicologia, organizações e trabalho no Brasil. Porto Alegre: Artmed, 2004. p. 443-463.

TRIANDIS, H. C.; KUROWSKI, L. L.; GELFAND, M. J. Workplace diversity. In: TRIANDIS, H. C.; DUNNETTE, M. D.; HOUGH, L. M. Handbook of industrial and organizational psychology. Palo Alto, California: Consulting Psychologists Press, I994. v. 4, p. 769-827.

TURNER, J. C. Towards a cognitive redefinition of the social group. In: TAJFEL, H. (Ed.). Social identity and intergroup relations. Cambridge: Cambridge University Press, I982. p. I5-40.

TZINER, A.; EDEN, D. Effects of crew composition on crew performance: does the whole equal the sum of its parts? Journal of Applied Psychology, Washington, DC, v. 70, p. 85-93, I985.

VISSER, P. S.; KROSNICK, J. A.; LAVRAKAS, P. J. Survey research. In: REIS, H. T.; JUDD, C. M. Handbook of research methods in social and personality psychology. Cambridge: Cambridge University Press, 2000. p. 223-252.

VLIERT, E. Van de. Conflict and conflict management. In: DRENTH, P. J. D.; THIERRY, H.; WOLF, C. J. de. (Ed.). Handbook of work and organizational psychology. East Sussex: Psychology Press. I998. p. 35I-376.

WILLIAMS, K. Y.; O'REILLY, C. A. Demography and diversity in organizations: a review of 40 years of research. In: STAW, B. M.; CUMMINGS L. L. (Ed.). Research in organizational behavior. Greenwich: JAI Press, I998. v. 20, p. 70-I40. 